\title{
TANNERY AND COAL MINING WASTE DISPOSAL ON $\operatorname{SOIL}^{(1)}$
}

\author{
Claudio Henrique Kray ${ }^{(2)}$, Marino José Tedesco ${ }^{(3)}$, Carlos Alberto Bissani ${ }^{(3)}$, Clesio \\ Gianello $^{(3)} \&$ Kelly Justin da Silva ${ }^{(4)}$
}

\section{SUMMARY}

Tannery residues and coal mine waste are heavily polluting sources in Brazil, mainly in the Southern States of Rio Grande do Sul and Santa Catarina. In order to study the effects of residues of chrome leather tanning (sludge and leather shavings) and coal waste on soybean and maize crops, a field experiment is in progress since 1996, at the Federal University of Rio Grande do Sul Experimental Station, county of Eldorado do Sul, Brazil. The residues were applied twice (growing seasons 1996/97 and 1999/00). The amounts of tannery residues were applied according to their neutralizing value, at rates of up to $86.8 \mathrm{t} \mathrm{ha}^{-1}$, supplying from 671 to $1.342 \mathrm{~kg} \mathrm{ha}^{-1} \mathrm{Cr}$ (III); coal waste was applied at a total rate of $164 \mathrm{t} \mathrm{ha}^{-1}$. Crop yield and dry matter production were evaluated, as well as the nutrients ( $, \mathrm{P}, \mathrm{K}, \mathrm{Ca}, \mathrm{Mg}, \mathrm{Cu}$ and $\mathrm{Zn}$ ) and $\mathrm{Cr}$ contents. Crop yields with tannery sludge application were similar to those obtained with $\mathrm{N}$ and lime supplied with mineral amendments. Plant $\mathrm{Cr}$ absorption did not increase significantly with the residue application. Tannery sludge can be used also to neutralize the high acidity developed in the soil by coal mine waste.

Index terms: Chromium tannery sludge, leather shavings, coal mine, heavy metal.

\footnotetext{
(1) Part of the Master's degree Dissertation of the first author, submitted to the Post Graduation Program of Soil Science, Universidade Federal do Rio Grande do Sul - UFRGS. Supported in part by the CNPq and by the Soil Testing Laboratory of the Soils Department - UFRGS. Paper presented at the XXXI Congress of the Brazilian Soil Science Society (Gramado, Rio Grande do Sul State).

(2) Professor at the Centro Federal de Educação Tecnológica, CEFET/BG. Av. Osvaldo Aranha 540, CEP $95700-000$ Bento Gonçalves (RS). E-mail: ckray@terra.com.br

(3) Professor of the Department of Soil Science, Universidade Federal do Rio Grande do Sul - UFRGS. Av Bento Gonçalves, 7712 , CEP 91540-000 Porto Alegre (RS).

(4) Graduate student, Escola Superior de Agricultura Luiz de Queiroz - ESALQ
} 


\title{
RESUMO: RESÍDUOS DO PROCESSAMENTO DE PELES E DE CARVÃO MINERAL APLICADOS EMSOLO
}

\begin{abstract}
Os resíduos gerados na exploração de carvão mineral e no processamento de peles são produtos potencialmente poluentes em várias regiões do Brasil, principalmente nos Estados do Rio Grande do Sul e de Santa Catarina. O presente trabalho foi conduzido a campo com o objetivo de avaliar o efeito da aplicação e da reaplicação de resíduos carbonífero e de curtume ao Cr sobre as plantas de milho e de soja cultivadas em um Argissolo Vermelho distrófico típico, na Estação Experimental da UFRGS, localizada no município de Eldorado do Sul $(R S)$. A primeira aplicação dos resíduos foi feita no ano agrícola de 1996/97 e a reaplicação no ano agrícola de 1999/2000. As doses de resíduos de curtume variaram conforme o $\mathrm{pH}$ do solo e o poder de neutralização do resíduo, tendo sido adicionadas quantidades cumulativas de Cr entre 671 a 1,342 $\mathrm{kg} \mathrm{ha}^{-1}$. A quantidade acumulada de resíduo carbonífero foi de $164 t \mathrm{ha}^{-1}$. Foram avaliados os efeitos das aplicações dos resíduos sobre o rendimento e a absorção de $\mathrm{N}, \mathrm{P}, \mathrm{K}, \mathrm{Ca}, \mathrm{Mg}, \mathrm{Cu}, \mathrm{Zn}$ e Cr pelas plantas. A adição de lodo de curtume propiciou rendimentos de milho e de soja semelhantes aos obtidos com a adição de $N$ mineral e de corretivo da acidez. Não foram observadas alterações significativas na absorção de Cr pelas plantas. $O$ efeito acidificante do solo apresentado pelo resíduo carbonífero pode ser controlado por aplicações adequadas de lodo de curtume alcalino.
\end{abstract}

Termos de indexação: cromo, lodo de curtume, metais pesados, resíduo carbonífero e serragem cromada.

\section{INTRODUCTION}

Coal mining, hide tanning and leather product industries are important economic activities in southern Brazil. They generate, however, high amounts of residues which pose potential pollution problems. Proper handling and disposal practices are therefore required. A field experiment was started in 1996 to study the effects of such residue applications to the soil on corn and soybean crops. First results were presented by Ferreira et al. (2003). The trial was resumed with applications of the same residue types when the soil $\mathrm{pH}$ dropped significantly, in the 1999/2000 summer season.

\section{MATERIAL AND METHODS}

An ongoing long-term field experiment that began in 1996 at the Federal University of the Rio Grande do Sul Experimental Station, is conducted on a Typic Paleudult soil, previously maintained under native pasture. At the beginning of the experiment, soil samples were collected at depths of $0-20 \mathrm{~cm}$ and $50-80 \mathrm{~cm}$. The $\mathrm{pH}$ in the surface layer was 4.9 (1:1 water suspension); clay and organic matter contents were 250 and $25.0 \mathrm{~g} \mathrm{dm}^{-3}$, respectively. The complete soil characterization is given by Ferreira et al. (2003).

The soil in the experimental area $\left(30^{\circ} 05^{\prime} 76^{\prime \prime} \mathrm{S}\right.$ and $51^{\circ} 40^{\prime} 67^{\prime \prime} \mathrm{W}$ ) had low $\mathrm{P}$ and high K contents. In the 1996/97 growing season the area was prepared for planting by plowing and disking. The residues (Table 1) were broadcast and mixed with the soil surface layer (0 to $20 \mathrm{~cm}$ ). Tannery residues were obtained at the UTRESA (a waste-treatment station) and coal mine refuse from the COPELMI mine, near the experimental site.

The treatments (with four replications) are described in table 2 . The plots $(10 \times 7 \mathrm{~m})$ were divided to grow corn (Zea mays, L) and soybean (Glycine max, L. Merrill), sown on January 13, 2000. In the fertilized plots, 120 and $50 \mathrm{~kg} \mathrm{ha}^{-1}$ of $\mathrm{P}_{2} \mathrm{O}_{5}$ (triple superphosphate) and $\mathrm{K}_{2} \mathrm{O}(\mathrm{KCl})$, respectively, were added, according to regional fertilizer recommendations (SBCS/NRS, 1995). For corn, $160 \mathrm{~kg} \mathrm{ha}^{-1} \mathrm{~N}$ (urea) was also added to the treatments with $\mathrm{N}$ fertilization (Table 2). Soybean was properly inoculated prior to sowing. The experimental area was sprinkle-irrigated as required.

Soil samples were taken from the surface $(0$ - 20 $\mathrm{cm})$ and subsurface $(50-80 \mathrm{~cm}$ ) layers 960 days after the first residue application. Similar soil samples were also taken six months after the second residue application (in July, 2000). Soil samples of the surface layer $(0-30 \mathrm{~cm})$ were taken 30 days after the second residue application from the treatments T4, T6 and T8, these samples were transported without drying to the laboratory for $\mathrm{Cr}(\mathrm{VI})$ determination (without drying), according to a method described by Bartlett \& James (1996).

At the grain filling stage, four corn and 20 soybean plants of each plot were harvested to determine the dry matter production, nutrients $(\mathrm{N}, \mathrm{P}, \mathrm{K}, \mathrm{Ca}, \mathrm{Mg}$, $\mathrm{Zn}$ and $\mathrm{Cu}$ ) and $\mathrm{Cr}$ contents, according to the method described by Tedesco et al. (1995). 
Table 1. Description of the residues applied

\begin{tabular}{|c|c|c|c|c|c|c|}
\hline \multirow{2}{*}{ Determination (1) } & \multicolumn{2}{|c|}{ Tannery sludge } & \multicolumn{2}{|c|}{ Leather shavings } & \multicolumn{2}{|c|}{ Coal mine refuse } \\
\hline & $I^{(3)}$ & $\mathbf{I I}^{(3)}$ & I & II & I & II \\
\hline Solid content ( $\left.\mathrm{g} \mathrm{kg}^{-1}\right)$ & 390 & 300 & 460 & 480 & 905 & 925 \\
\hline pH (water) & 7.8 & 7.7 & 3.4 & 3.3 & 7.1 & 7.0 \\
\hline Organic carbon $\left(\mathrm{g} \mathrm{kg}^{-1}\right)$ & 65.1 & 203.8 & 298.3 & 326.0 & 242.9 & 183.8 \\
\hline Nitrogen $^{(2)}\left(\mathrm{g} \mathrm{kg}^{-1}\right)$ & 9.8 & 32.5 & 113.1 & 119.7 & 3.6 & 2.3 \\
\hline Phosphorus $^{(2)}\left(\mathrm{g} \mathrm{kg}^{-1}\right)$ & 2.0 & 2.5 & 0.3 & 0.4 & 0.3 & 0.3 \\
\hline $\operatorname{Potassium}^{(2)}\left(\mathrm{g} \mathrm{kg}^{-1}\right)$ & 0.10 & 0.12 & 0.10 & 0.12 & 0.07 & 0.06 \\
\hline Calcium $^{(2)}\left(\mathrm{g} \mathrm{kg}^{-1}\right)$ & 20.0 & 22.0 & 17.9 & 18.0 & 18.6 & 19.0 \\
\hline $\operatorname{Magnesium}^{(2)}\left(\mathrm{g} \mathrm{kg}^{-1}\right)$ & 0.2 & 3.5 & 0.2 & 0.2 & 0.7 & 0.7 \\
\hline $\operatorname{Sulfur}^{(2)}\left(\mathrm{g} \mathrm{kg}^{-1}\right)$ & 13.0 & 15.0 & 16.5 & 15.9 & 83.6 & 85.0 \\
\hline $\operatorname{Copper}^{(2)}\left(\mathrm{mg} \mathrm{kg}^{-1}\right)$ & 19 & 34 & 5 & 3 & 23 & 25 \\
\hline $\operatorname{Zinc}^{(2)}\left(\mathrm{mg} \mathrm{kg}^{-1}\right)$ & 112 & 176 & 7 & 2 & 207 & 126 \\
\hline $\operatorname{Manganese}^{(2)}\left(\mathrm{mg} \mathrm{kg}^{-1}\right)$ & 262 & 128 & $<3$ & $<3$ & 541 & 194 \\
\hline $\operatorname{Sodium}^{(2)}\left(\mathrm{g} \mathrm{kg}^{-1}\right)$ & 8.4 & 8.1 & 7.0 & 4.3 & ND & ND \\
\hline Chromium $^{(2)}\left(\mathrm{g} \mathrm{kg}^{-1}\right)$ & 8.1 & 22.2 & 21.0 & 24.0 & $<0.1$ & 0.3 \\
\hline $\operatorname{Cadmium}^{(2)}\left(\mathrm{mg} \mathrm{kg}^{-1}\right)$ & 0.14 & 0.14 & $<0.01$ & $<0.01$ & 13.02 & 12.85 \\
\hline $\operatorname{Nickel}^{(2)}\left(\mathrm{mg} \mathrm{kg}^{-1}\right)$ & 15.0 & 14.5 & 3.1 & 3.2 & 19.8 & 19.2 \\
\hline Neutralizing value (\%) & 16.0 & 31.5 & $\mathrm{ND}^{(4)}$ & ND & ND & ND \\
\hline
\end{tabular}

${ }^{(1)}$ Determinations of the oven-dried material, except for $\mathrm{pH} .{ }^{(2)}$ Total amount. ${ }^{(3)}$ Residues applied by Ferreira et al. (2003) and in this study, respectively (Kray, 2001). ${ }^{(4)} \mathrm{ND}=$ not determined.

Table 2. Treatments, residue amounts applied and chromium added ${ }^{(1)}$

\begin{tabular}{|c|c|c|c|c|c|}
\hline \multirow{2}{*}{ Treatments } & \multicolumn{2}{|c|}{$\begin{array}{l}\text { First application } \\
\text { (1996) }\end{array}$} & \multicolumn{2}{|c|}{ Second application (2000) } & \multirow{2}{*}{$\begin{array}{c}\mathrm{Cr} \\
\text { added }\end{array}$} \\
\hline & Residue & Lime & Residue & Lime & \\
\hline & & & ha ${ }^{-1}$ & - & kg ha-1 \\
\hline T1 - Blank & - & - & - & - & - \\
\hline $\begin{array}{l}\text { T2 - NPK fertilizer + lime to reach pH } \\
\text { 6,0 (NPK+ lime) }\end{array}$ & - & 3.4 & - & 6.3 & - \\
\hline $\begin{array}{l}\text { T3 - Tannery sludge to reach pH } 6,0+ \\
\text { PK (TS+PK); }\end{array}$ & $21.2 \mathrm{TS}$ & - & $22.4 \mathrm{TS}$ & - & $671^{(2)}$ \\
\hline $\begin{array}{l}\text { T4 - Twice the amount of tannery } \\
\text { sludge applyed on treatment } 3+ \\
\text { PK }(2 x T S+P K)\end{array}$ & $42.4 \mathrm{TS}$ & - & $44.8 \mathrm{TS}$ & - & $1,342^{(2)}$ \\
\hline $\begin{array}{l}\text { T5 - Coal waste + lime to reach pH } 6.0 \\
\text { + NPK (CR+lime +NPK) }\end{array}$ & 106.0 CR & 3.4 & $56.0 \mathrm{CR}$ & 20.0 & $<0,02(2)$ \\
\hline $\begin{array}{l}\text { T6 - Coal waste + tannery sludge to } \\
\text { reach pH } 6.0+\mathrm{PK}(\mathrm{CR}+\mathrm{TS}+\mathrm{PK})\end{array}$ & $\begin{array}{r}106.0 \mathrm{CR} \\
21.2 \mathrm{TS}\end{array}$ & - & $\begin{array}{l}56.0 \mathrm{CR} \\
34.4 \mathrm{TS}\end{array}$ & - & $937^{(2)}$ \\
\hline $\begin{array}{c}\text { T7 - Leather shavings + lime to reach } \\
\text { pH } 6.0+\text { NPK }(\mathrm{LS}+\text { lime+NPK) }\end{array}$ & $29.4 \mathrm{LS}$ & 3.4 & $30.0 \mathrm{LS}$ & 8.6 & $1,337^{(2)}$ \\
\hline $\begin{array}{l}\text { T8 - Cr sulfate + tannery sludge to } \\
\text { reach } \mathrm{pH} 6.0+\mathrm{PK}\left(\mathrm{Cr}_{\mathrm{m}}+\mathrm{TS}+\mathrm{PK}\right)\end{array}$ & $\begin{array}{l}21.2 \mathrm{TS} \\
0.125 \mathrm{Cr}_{\mathrm{m}}^{(3)}\end{array}$ & - & $\begin{array}{l}22.4 \mathrm{TS} \\
0.500 \mathrm{Cr}_{\mathrm{m}}\end{array}$ & - & $1,296^{(4)}$ \\
\hline
\end{tabular}




\section{RESULTS AND DISCUSSION}

\section{Soil $\mathrm{pH}$ values and $\mathrm{Cr}$ contents}

The residual effects of the first residue application were evaluated 960 days after soil sampling (Table $3)$. It was observed that tannery sludge was effective to maintain the $\mathrm{pH}$ values at a similar level to liming (T3 and T8). Higher amounts are however required to maintain an adequate $\mathrm{pH}$ level over longer periods (T4). The same occurs when coal mine refuse is applied, due to the acid-forming capacity of this residue by pyrite oxidation ( $\mathrm{T} 5$, T6). Alkaline tannery sludge and acidifying coal mine refuse could therefore be applied in proper amounts to maintain adequate soil $\mathrm{pH}$ values for plant growth (5.5 to 6.5).

The acidifying capacity of coal residue was observed in the subsurface soil layer $(50-80 \mathrm{~cm})$ 960 days after sampling, reaching a $\mathrm{pH}$ value of 3.9 in treatment T5, despite lime application (Table 3). Liming should be applied more frequently in this case.

Chromium contents in the soil surface layer increased with tannery residue application and addition of $\mathrm{Cr}$ sulfate (Table 4). Chromium recovery was however low, reaching values from 23 to $43 \%$ of the applied amounts. Low Cr recovery values are often reported (Castilhos et al., 2002; Ferreira et al., 2003; Domaszak, 2000). This can be due to the coarse particle segregation of the residues during sample preparation (Domaszak, 2000) or to the low solubility of compound formation with soil minerals.

No Cr translocation to the soil subsurface layer was observed, in agreement with previous reports in the literature (Castilhos et al., 2002; Ferreira et al., 2003; Domaszak, 2000). Even with Cr sulfate application (T8), no $\mathrm{Cr}(\mathrm{VI})$ formation was detected in the soil surface layer.

\section{Grain yields and plant Cr contents}

The plant dry matter production increased with residue application, with adequate liming and fertilization (Table 5). The dry matter production increase was however lower in the treatments with coal waste application, due to the lower $\mathrm{pH}$ in the subsurface soil layer (T5 and T6), mainly in corn. A smaller increase was also stated in the treatment with LS application, probably due to P immobilization by soil microorganisms, as previously observed (Ferreira, 2002). Grain yields followed the same general pattern observed for plant dry matter production.

It was observed that $\mathrm{Cr}$ translocation to the plant tops was low, in the mean 3.5 times lower in the grain than in the dry matter $\left(0.30\right.$ and $1.05 \mathrm{mg} \mathrm{kg}^{-1}$, respectively) (Figure 1), as previously reported in the literature (Castilhos et al., 2002; Ferreira et al., 2003). The determined values were within the range usually found in plants growing on uncontaminated soil (Kabata-Pendias \& Pendias, 1986; Pais \& Benton-Jones 1997).

Table 3. $\mathrm{pH}$ values (1:1 water suspension) of the soil top layer (0-20 $\mathrm{cm}$ depth) at three sampling times (two after the first residue application and one after the second) and of the soil subsurface layer $(50-80 \mathrm{~cm}$ depth) at two sampling times

\begin{tabular}{|c|c|c|c|c|c|}
\hline \multirow{3}{*}{ Treatment } & \multicolumn{3}{|c|}{ After first application } & \multicolumn{2}{|c|}{ After second application } \\
\hline & \multicolumn{2}{|c|}{$0-20 \mathrm{~cm}$} & \multirow{2}{*}{$\begin{array}{l}50-80 \mathrm{~cm} \\
960 \text { days }\end{array}$} & $0-20 \mathrm{~cm}$ & $50-80 \mathrm{~cm}$ \\
\hline & 180 days & 960 days & & \multicolumn{2}{|c|}{180 days } \\
\hline 1 - Blank & $5.2 \mathrm{c} \mathrm{A}$ & $4.5 \mathrm{c} \mathrm{B}$ & $4.4 \mathrm{a}$ & $4.9 \mathrm{~d} \mathrm{AB}$ & $4.6 \mathrm{a}$ \\
\hline 2 - NPK + lime & $5.9 \mathrm{ab} \mathrm{A}$ & $5.1 \mathrm{ab} B$ & $4.4 \mathrm{a}$ & $6.2 \mathrm{bc} \mathrm{A}$ & $4.6 \mathrm{a}$ \\
\hline $3-\mathrm{TS}+\mathrm{PK}$ & 6.0 a B & $5.1 \mathrm{ab} \mathrm{C}$ & $4.3 \mathrm{a}$ & $6.7 \mathrm{ab} \mathrm{A}$ & $4.7 \mathrm{a}$ \\
\hline $4-2 \mathrm{xTS}+\mathrm{PK}$ & 6.2 a B & 5.4 a C & $4.3 \mathrm{a}$ & $7.1 \mathrm{a} \mathrm{A}$ & $4.7 \mathrm{a}$ \\
\hline $5-\mathrm{CR}+$ lime + NPK & $5.0 \mathrm{c} \mathrm{A}$ & $3.4 \mathrm{~d} \mathrm{~B}$ & $3.9 \mathrm{~b}$ & $5.3 \mathrm{~d} A$ & $4.3 \mathrm{~b}$ \\
\hline $6-\mathrm{CR}+\mathrm{TS}+\mathrm{PK}$ & 6.3 a $\mathrm{A}$ & $4.4 \mathrm{c} \mathrm{B}$ & $4.1 \mathrm{~b}$ & $6.6 \mathrm{ab} \mathrm{A}$ & $4.4 \mathrm{~b}$ \\
\hline $7-\mathrm{LS}+$ lime + NPK & $5.4 \mathrm{bc} \mathrm{AB}$ & $4.7 \mathrm{bc} \mathrm{B}$ & $4.3 \mathrm{a}$ & 5.9 с A & $4.6 \mathrm{a}$ \\
\hline $8-\mathrm{Cr}_{\mathrm{m}}+\mathrm{TS}+\mathrm{PK}$ & $5.9 \mathrm{ab} \mathrm{B}$ & $5.1 \mathrm{ab} \mathrm{C}$ & $4.4 \mathrm{a}$ & $6.4 \mathrm{bc} \mathrm{A}$ & $4.6 \mathrm{a}$ \\
\hline
\end{tabular}

Means followed by the same lower case letter, in a column (treatments) and by the same upper case letter, in a row (sampling times) were not significantly different by the Tukey test $(\mathrm{p}<0.05)$. 
Table 4. Chromium contents ${ }^{(1)}$ of the surface soil layer $(0-20 \mathrm{~cm})$ at three sampling times (one after the first residue application and two after the second) and of the subsurface layer $(50-80 \mathrm{~cm} \mathrm{depth})$ at two sampling times

\begin{tabular}{|c|c|c|c|c|c|}
\hline \multirow{3}{*}{ Treatment } & \multirow{2}{*}{\multicolumn{2}{|c|}{$\begin{array}{c}\text { After first application } \\
960 \text { days }\end{array}$}} & \multicolumn{3}{|c|}{ After second application } \\
\hline & & & \multirow{2}{*}{$\begin{array}{l}30 \text { days } \\
0-20 \mathrm{~cm}\end{array}$} & \multicolumn{2}{|c|}{180 days } \\
\hline & $0-20 \mathrm{~cm}$ & $50-80 \mathrm{~cm}$ & & $0-20 \mathrm{~cm}$ & $50-80 \mathrm{~cm}$ \\
\hline & & & $\mathrm{mg} \mathrm{kg}^{-1}$ & & \\
\hline 1 - Blank & $14 \mathrm{~b} \mathrm{~A}$ & 14 & $10 \mathrm{~d} A$ & $12 \mathrm{~d} \mathrm{~A}$ & 13 \\
\hline 2 - NPK + lime & $12 \mathrm{~b} \mathrm{~A}$ & 16 & $14 \mathrm{~d} \mathrm{~A}$ & $15 \mathrm{~d} \mathrm{~A}$ & 13 \\
\hline $3-\mathrm{TS}+\mathrm{PK}$ & $68 \mathrm{ab} \mathrm{B}$ & 14 & $114 \mathrm{c} \mathrm{AB}$ & 132 с A & 14 \\
\hline $4-2 \mathrm{xTS}+\mathrm{PK}$ & 112 a B & 16 & $179 \mathrm{~b} \mathrm{~A}$ & 181 bc A & 14 \\
\hline 5 - CR+lime + NPK & $12 \mathrm{~b} \mathrm{~A}$ & 14 & $12 \mathrm{~d} \mathrm{~A}$ & $11 \mathrm{~d} \mathrm{~A}$ & 13 \\
\hline $6-\mathrm{CR}+\mathrm{TS}+\mathrm{PK}$ & 115 a B & 16 & $176 \mathrm{~b} \mathrm{~A}$ & $194 \mathrm{~b} \mathrm{~A}$ & 13 \\
\hline $7-\mathrm{LS}+$ lime + NPK & 95 a B & 17 & $135 \mathrm{bc} \mathrm{AB}$ & $151 \mathrm{bc} \mathrm{A}$ & 14 \\
\hline $8-\mathrm{Cr}_{\mathrm{m}}+\mathrm{TS}+\mathrm{PK}$ & 98 a B & 16 & 290 a A & 279 a A & 14 \\
\hline
\end{tabular}

(1) Extracted with concentrated $\mathrm{HNO}_{3}+\mathrm{HClO}_{4}$ acids.

Averages followed by the same lower case letter, in a column (treatments) and by the same upper case letter, in a row (sampling times) were not significantly different by the Tukey test $(p<0.05)$.

Table 5. Plant dry matter production and grain yield in the 1999/2000 growing season

\begin{tabular}{|c|c|c|c|c|}
\hline \multirow{2}{*}{ Treatment } & \multicolumn{2}{|c|}{ Dry matter } & \multicolumn{2}{|c|}{ Yield } \\
\hline & Soybean & Corn & Soybean & Corn \\
\hline & \multicolumn{2}{|c|}{ g plant ${ }^{-1}$} & \multicolumn{2}{|c|}{$\mathrm{t} \mathrm{ha}^{-1}$} \\
\hline 1 - Blank & $6.80 \mathrm{~b}$ & $82.9 \mathrm{c}$ & $1.24 \mathrm{~b}$ & $3.27 \mathrm{c}$ \\
\hline 2 - NPK + lime & $12.33 \mathrm{a}$ & $162.4 \mathrm{ab}$ & $2.78 \mathrm{a}$ & $8.60 \mathrm{a}$ \\
\hline $3-\mathrm{TS}+\mathrm{PK}$ & $13.78 \mathrm{a}$ & $176.9 \mathrm{a}$ & $2.81 \mathrm{a}$ & $8.61 \mathrm{a}$ \\
\hline $4-2 \mathrm{xTS}+\mathrm{PK}$ & $13.37 \mathrm{a}$ & $175.4 \mathrm{a}$ & $2.83 \mathrm{a}$ & $8.71 \mathrm{a}$ \\
\hline $5-\mathrm{CR}+$ lime $+\mathrm{NPK}^{(2)}$ & $10.93 \mathrm{a}$ & $138.6 \mathrm{~b}$ & $2.82 \mathrm{a}$ & $6.91 \mathrm{~b}$ \\
\hline $6-\mathrm{CR}+\mathrm{TS}+\mathrm{PK}$ & $12.78 \mathrm{a}$ & $152.0 \mathrm{ab}$ & $2.87 \mathrm{a}$ & $8.70 \mathrm{a}$ \\
\hline $7-\mathrm{LS}+$ lime + NPK & $11.43 \mathrm{a}$ & $169.1 \mathrm{ab}$ & $2.76 \mathrm{a}$ & $6.90 \mathrm{~b}$ \\
\hline $8-\mathrm{Cr}_{\mathrm{m}}+\mathrm{TS}+\mathrm{PK}$ & $11.30 \mathrm{a}$ & $171.8 \mathrm{a}$ & $2.88 \mathrm{a}$ & $8.50 \mathrm{a}$ \\
\hline
\end{tabular}

Means followed by the same letter, in a column, were not significantly different by the Tukey test $(\mathrm{p}<0.05)$.

According to the State legislation of Rio Grande do Sul, up to $1,000 \mathrm{~kg} \mathrm{ha}^{-1}$ of $\mathrm{Cr}$ per hectare may be applied in tannery residues (Rodrigues et al., 1993). Higher amounts were applied here ( treatments T4 and T7), with no harmful effects. There is no agreement between legislations on the maximum allowable $\mathrm{Cr}$ addition to the soil with organic residues. While some normative institutions do not mention maximum values (USEPA, 1996; CEC,
1986), others have conservative limits, as the Brazilian CONAMA (2006), which allows a $\mathrm{Cr}$ application of up to $154 \mathrm{~kg} \mathrm{ha}^{-1}$ with sewage sludge. The naturally occurring $\mathrm{Cr}$ contents in several soils in Brazil exceed this limit.

In the fertilized treatments (T2 to T8), plant nutrient contents $(\mathrm{N}, \mathrm{P}, \mathrm{K}, \mathrm{Ca}, \mathrm{Mg}, \mathrm{Cu}$ and $\mathrm{Zn})$ in the dry matter were in the range considered adequate for plant growth (SBCS/NRS, 2004). 

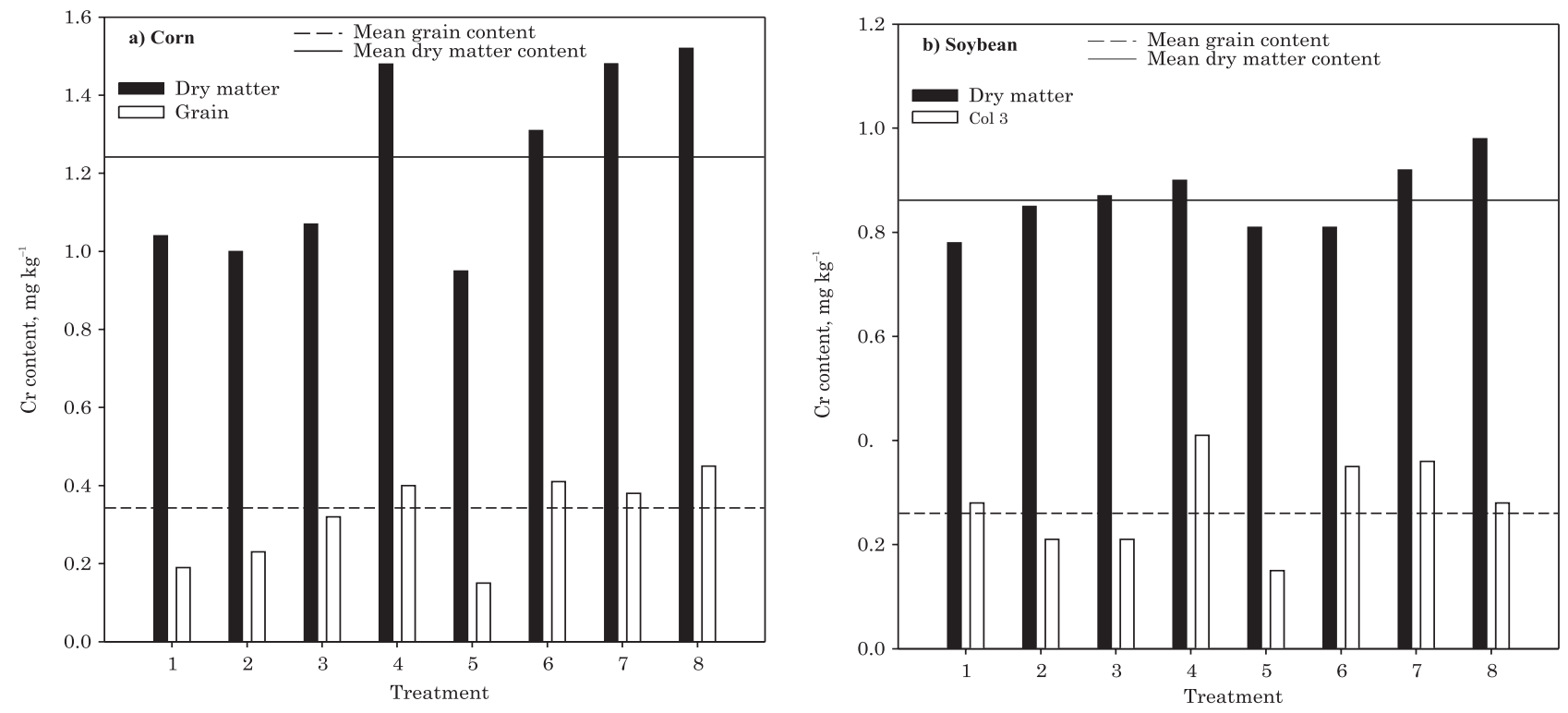

Figure 1. Plant dry matter (after flowering) and grain chromium contents.

\section{CONCLUSIONS}

1. Alkaline tannery sludge can be efficient in neutralizing soil acidity and represent a source of some plant nutrients, mainly $\mathrm{N}$.

2. Chromium translocation to the plant tops was minor, and even smaller to grain. Cr(III) was very immobile in the soil and no oxidation to $\mathrm{Cr}(\mathrm{VI})$ was observed, even when Cr sulfate was added to the soil with tannery sludge.

\section{LITERATURE CITED}

BARTLETT, R.J. \& JAMES, B.R. Chromium. In: SPARKS, D.L. ed. Methods of soil analysis. Madison: Soil Science Society of America, 1996. part.3, n.5, p.683-701.

CASTILHOS, D.D.; TEDESCO, M.J. \& VIDOR, C. Rendimento de culturas e alterações químicas do solo tratado com resíduos de curtume e crômio hexavalente. R. Bras. Ci. Solo, 26: 1083-1092, 2002.

CEC (Council of European Communities). Council directive on the protection of the environment and in particular of the soil, when sewage sludge is used in agriculture. Official Journal of the European Communities, $\mathrm{N}^{\circ} \mathrm{L} 181$ (29):6-12. 1986.

CONAMA (Conselho Nacional do Meio Ambiente). Resolução $n^{\circ}$. 375, de 29 de outubro de 2006. Diário Oficial da União. Brasilia, DF, 2006.

DOMASZAK, S.C. Efeito imediato e residual da aplicação de resíduos de curtume nas plantas em três solos. Porto Alegre, 2000. 107f. Dissertação (Mestrado) - Programa de Pós Graduação em Ciência do Solo, Faculdade de Agronomia, Universidade Federal do Rio Grande do Sul, Porto Alegre, 2000.
FERREIRA, A.S.; CAMARGO, F.A.O; TEDESCO, M.J. \& BISSANI. C.A. Alterações de atributos químicos e biológicos de solo e rendimento de milho e soja pela utilização de resíduos de curtume e carbonífero. R. Bras. Ci. Solo, 27: 755-763, 2003.

KABATA-PENDIAS, A. \& PENDIAS, H. Trace elements in soils and plants. 4.ed. Florida: CRC, 1986. 315p.

KRAY, C.H. Efeitos da aplicação e da reaplicação de resíduos carbonífero e de curtume no solo e nas plantas: Porto Alegre, 2001. 91f. Dissertação (Mestrado) - Programa de Pós Graduação em Ciência do Solo, Faculdade de Agronomia, Universidade Federal do Rio Grande do Sul, Porto Alegre, 2001.

PAIS, I. \& BENTON JONES, J. Jr. The handbook of trace elements. St. Lucie Press, Boca Raton, Florida. 223 p. 1997.

RODRIGUES, A.L.M.; ANGHINONI, M.C.M.; TEDESCO, M.J. \& GIANELLO, C. Critérios técnicos para disposição no solo de resíduos sólidos de curtume. In: CONGRESSO DA UNIÃO INTERNACIONAL DOS QUÍMICOS E TÉCNICOS DA INDÚSTRIA DO COURO, 22., 1993, Porto Alegre. Boletim. Porto Alegre: FEPAM, 1993. 14p.

SBCS/NRS (Sociedade Brasileira de Ciência do Solo/Núcleo Regional Sul). Recomendações de adubação e de calagem para os estados do Rio Grande do Sul e de Santa Catarina. 3. ed. Passo Fundo: Embrapa-CNPT, 1995. 224p.

SBCS/NRS (Sociedade Brasileira de Ciência do Solo/Núcleo Regional Sul). Manual de adubação e calagem para os Estados do Rio Grande do Sul e de Santa Catarina. 10. ed. Porto Alegre, 2004. 400p.

TEDESCO, M.J.; GIANELLO, C.; BISSANI, C.A.; BOHNEN, H. \& VOLKWEISS, S.J. Análises de solos, plantas e outros materiais. 2.ed. Porto Alegre: Departamento de Solos da Faculdade de Agronomia, UFRGS, 1995. 174p. (Boletim Técnico, 5).

USEPA (United States Environmental Protection Agency). Standards for the use and disposal of sewage sludge. Washington, EPA, 1996 (Code of Federal Regulations, 40, Part 503) - Hill Book Company. 751p. 